UDC 338.43:664.7

\author{
Fomichova K. \\ Postgraduate \\ Department of Management of Business \\ Odessa National Academy of Food Technologies \\ Kanatna str., 112, Odesa, Ukraine, 65039 \\ E-mail: ket1588@mail.ru
}

\title{
TRENDS IN THE GRAIN MARKET OF UKRAINE
}

This article explores the current state of the grain industry in Ukraine, the main problems and trends of its development in the current economic conditions. The export potential of grain production has been investigated, economic feasibility and prospects of grain industry development in Ukraine have been grounded, the amount of production and cereals consumption in the world have been analyzed and summarized.

Keywords: agriculture, grain market, productivity, export potential, global market of cereals.

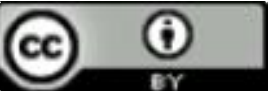

This work is licensed under a Creative Commons Attribution 4.0 International License http://creativecommons.org/licenses/by/4.0/

Statement of the problem and its connection with important scientific and practical tasks. The grain sector of Ukraine is a strategic sector of the economy of the country, which determines the volume of supply and the cost of the main types of food for the population, particularly products of grain processing and livestock production; generates a significant share of agricultural incomes; determines the status and trends of rural areas; generates foreign exchange revenues of the country at the expense of exports. Grain industry is a source of sustainable development of most sectors of agriculture and agricultural exports foundation of the country.

The analysis of the latest publications on the problem. Problems associated with the development of the grain industry in Ukraine, are widely reflected in the agricultural economics literature. The most comprehensive works are: Sabluk P.T., Shpychak O.M., Boyko V.I., Lobas M.G., Volynets V.L., Nikishina O.V., Andriychuk V.G., Kvasha S. M., Prysyazhnyuk M.V. Rozgon A.V., Pidlisetskyy G.M. and other scientists.

Stating the importance of scientific results in the theory and practice efficiency and development of the grain market, it should be noted that the issues of the comprehensive solution of the production and sales of grain in the condition of regional and national grain markets formation haven't been investigated well enough yet.

Forming of the aims of the research.The grain complex is important for Ukraine and the world economy as a whole. In solution of the problem of food independence, grain and its products are of particular importance as a strategic food, suitable for long storage and transportation. The aim is to highlight the current state of grain production in Ukraine and analyze the dynamic trend of development in the future.

Giving an account of the main results and their substantiation. Grain market is a system of commoditymoney relations arising between the subjects in the process of production, storage, trade and use of the grain, based on free competition, free choice directions of grain distribution and determining prices and state control over its quality and storage [1].

Over the last five years Ukraine has strengthened its position in the international agricultural market and is confident in the global top ten producers of grain. It is a leader in the production of sunflower and sunflower oil exports, and joined the top five leaders on grain exports.

Table 1

Common indicators of basic cereals in Ukraine [2]

\begin{tabular}{|c|c|c|c|c|c|c|c|c|c|}
\hline & \multicolumn{3}{|c|}{ Wheat } & \multicolumn{3}{|c|}{ Barley } & \multicolumn{3}{|c|}{ Corn } \\
\hline & $2014 / 2015$ & $2015 / 2016$ & $2016 / 2017$ & $2014 / 2015$ & $2015 / 2016$ & 2016/2017 & $2014 / 2015$ & $2015 / 2016$ & $2016 / 2017$ \\
\hline $\begin{array}{l}\text { Area } \\
\text { Harvested } \\
(1000 \text { HA) }\end{array}$ & 6,300 & 7,115 & 6,450 & 3,200 & 3,000 & 3,050 & 4,625 & 4,085 & 4,250 \\
\hline $\begin{array}{l}\text { Beginning } \\
\text { Stocks } \\
(1000 \mathrm{MT})\end{array}$ & 3,670 & 5,678 & 3,248 & 971 & 1,256 & 909 & 2,402 & 1,819 & 585 \\
\hline $\begin{array}{l}\text { Production } \\
(1000 \mathrm{MT})\end{array}$ & 27,750 & 27,274 & 26,800 & 9,450 & 8,751 & 9,900 & 28,450 & 23,333 & 27,000 \\
\hline
\end{tabular}


Continue of table 1

\begin{tabular}{|l|c|c|c|c|c|c|c|c|c|}
\hline & \multicolumn{3}{|c|}{ Wheat } & \multicolumn{4}{c|}{ Barley } & \multicolumn{4}{c|}{ Corn } \\
\cline { 2 - 11 } & $2014 / 2015$ & $2015 / 2016$ & $2016 / 2017$ & $2014 / 2015$ & $2015 / 2016$ & $2016 / 2017$ & $2014 / 2015$ & $2015 / 2016$ & $2016 / 2017$ \\
\hline $\begin{array}{l}\text { TY Imports } \\
(1000 \text { MT })\end{array}$ & 27 & 27 & 25 & 0 & 5 & 5 & 28 & 28 & 50 \\
\hline $\begin{array}{l}\text { Total Supply } \\
\text { (1000 MT) }\end{array}$ & 28,447 & 32,979 & 30,073 & 10,421 & 10,021 & 10,814 & 30,880 & 25,180 & 28,635 \\
\hline $\begin{array}{l}\text { TY Exports } \\
(1000 \text { MT) }\end{array}$ & 11,269 & 17,431 & 16,500 & 4,332 & 4,673 & 5,000 & 19,661 & 16,595 & 18,700 \\
\hline $\begin{array}{l}\text { Total Con- } \\
\text { sumption } \\
(1000 \text { MT) }\end{array}$ & 11,500 & 12,300 & 11,300 & 4,700 & 4,700 & 4,900 & 9,400 & 8,000 & 8,400 \\
\hline $\begin{array}{l}\text { Ending } \\
\text { stocks } \\
(1000 \text { MT) }\end{array}$ & 5,678 & 3,248 & 2,273 & 1,265 & 909 & 914 & 1,819 & 585 & 1,535 \\
\hline $\begin{array}{l}\text { Total } \\
\text { Distribution } \\
(1000 \text { MT) }\end{array}$ & 28,447 & 32,979 & 30,073 & 10,421 & 10,021 & 10,814 & 30,880 & 25,180 & 28,635 \\
\hline $\begin{array}{l}\text { Yield } \\
\text { (MT/HA) }\end{array}$ & 4,40 & 3,83 & 4,16 & 2,92 & 2,95 & 3,25 & 6,15 & 5,71 & 6,35 \\
\hline
\end{tabular}

According to the regions in 2016, the production of grain in total summary weight within 64.2 million tons, that is 4.0 million tons more than in 2015, while yielding $44.8 \mathrm{c} /$ ha (more than $3.7 \mathrm{c} /$ ha than in 2015) including: wheat -26.8 million tons (less than 474 ths. tons) at a yield of $42.0 \mathrm{c} / \mathrm{ha}$ (up $3.3 \mathrm{c} / \mathrm{ha}$ ); corn -27.0 million tons ( 3.6 million tons more) at the yield of $63.5 \mathrm{c}$ / ha (up $6.4 \mathrm{c} / \mathrm{ha}$ ); barley - 9.9 million tons (up 1.2 million tons) at the yield of $32.5 \mathrm{c} /$ ha (up $3.1 \mathrm{c} / \mathrm{ha}$ ); rye 395.0 ths. tons (over 4 ths. tons) at the yield of $27.7 \mathrm{c} /$ ha (up $1.8 \mathrm{c} / \mathrm{ha}$ ); oats -510.1 ths. tons (more than 21.6 ths. tons) at the yield of $24.6 \mathrm{c} /$ ha (up $1.4 \mathrm{c} / \mathrm{ha}$ ); buckwheat -183.3 ths. tons (up 55.2 ths. tons) at the yield of $12.3 \mathrm{c} /$ ha (up $2.2 \mathrm{c} / \mathrm{ha}$ ); millet -189.1 ths. tons (less than 24.2 ths. tons) at the yield of $18.0 \mathrm{c} / \mathrm{ha}$ (below $0.9 \mathrm{~kg} / \mathrm{ha}$ ); rice -68 ths. tons (more than 5 ths. tons) at the yield of $56.5 \mathrm{c} /$ ha (up $3.5 \mathrm{c} / \mathrm{ha}$ ) [3].

As the country's domestic needs in grain are within 29 million tons every year, increasing of its total production affects the growth of export potential.

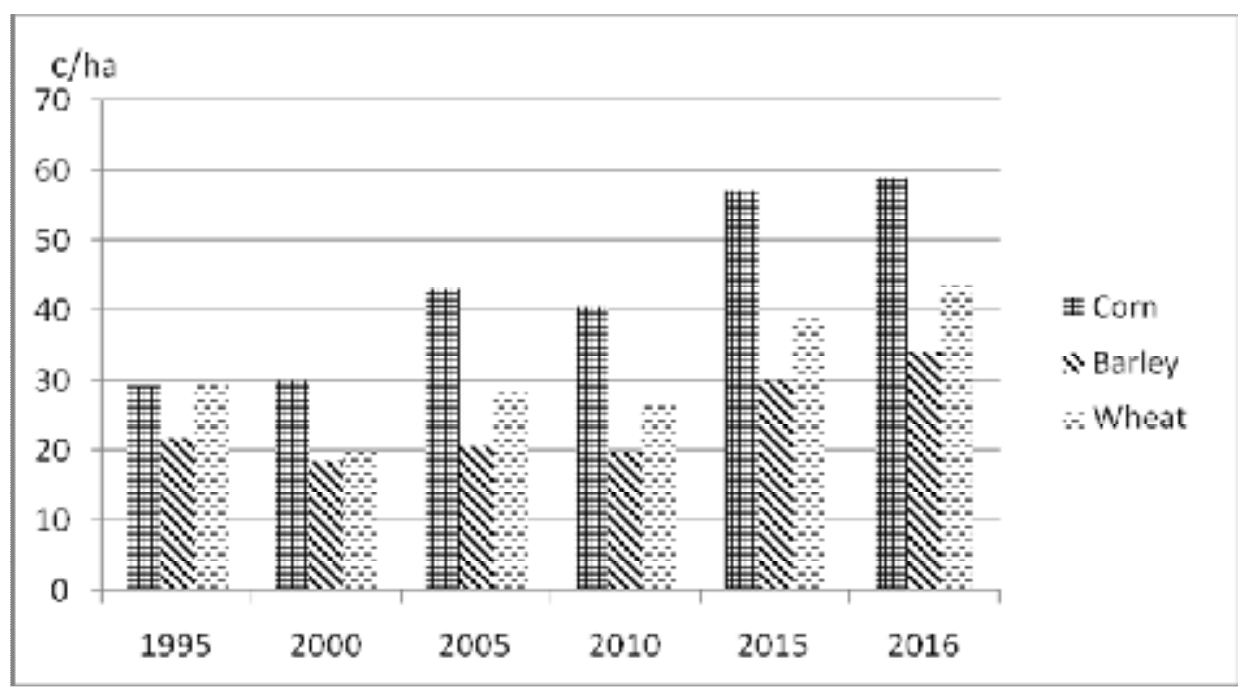

Pic.1. The growth yield of grain crops in Ukraine in the last 20 years (c/ha) [4]

Growth of basic grain cereals in Ukraine is significant. For twenty years the yield of wheat, corn and barley has grown by $69 \%$ on an average. The corn became the yield increase leader.

As for the world grain market indicators, the production of grain has a positive trend [5]. According to USDA's forecasts in 2016/17 marketing year, world grain production will be 2,269 billion tons, exceeding the previous season by 100.2 million tons. The increase in production will take place in all groups of grain. 
Table 2

All Grain Summary Comparison, Million Metric Tons [2]

\begin{tabular}{|l|c|c|c|c|c|c|c|c|c|}
\hline & \multicolumn{3}{|c|}{ Wheat } & \multicolumn{3}{c|}{ Barley } & \multicolumn{3}{c|}{ Corn } \\
\cline { 2 - 11 } & $2014 / 2015$ & $2015 / 2016$ & $2016 / 2017$ & $2014 / 2015$ & $2015 / 2016$ & $2016 / 2017$ & $2014 / 2015$ & $2015 / 2016$ & $2016 / 2017$ \\
\hline Production & 728,3 & 735,6 & 748,2 & 141,763 & 147,932 & 143,953 & 1015,6 & 960,7 & 1040,2 \\
\hline $\begin{array}{l}\text { Domestic } \\
\begin{array}{l}\text { Consump- } \\
\text { tion }\end{array}\end{array}$ & 700,4 & 709,6 & 735,9 & 142,471 & 145,471 & 145,562 & 964,6 & 979,0 & 1020,8 \\
\hline $\begin{array}{l}\text { Ending } \\
\text { stocks }\end{array}$ & 217,5 & 240,8 & 248,6 & 24,059 & 24,616 & 22,877 & 209,8 & 210,4 & 217,6 \\
\hline TY Imports & 159,0 & 168,7 & 175,6 & 28,896 & 28,037 & 26,646 & 125,7 & 138,4 & 139,9 \\
\hline TY Exports & 161,8 & 172,1 & 178,3 & 30,099 & 27,476 & 26,905 & 128,4 & 144,9 & 143,1 \\
\hline
\end{tabular}

Thus, the total wheat harvest will amount to 748.2 million tons that is 12.6 million tons more than in 2015. Production of barley in the world will decline slightly and will be 143,953 million tons. Forecasted corn production in the world has also increased. Thus, the expected production of corn in the world will amount to 1.04 billion tons that is 79.5 million tons higher than in 2015 [6].

The new grain season will have marked increase in the international trade activity. The total volume of grain exports will amount to 362.9 million tons, that is 5.6 million tons more than the previous season. Global grain stocks at the end of the 2016/2017 marketing year will reach 584.2 million tons, which exceeds the previous level by 16 million tons.

According to the Ministry of Agriculture and Food, Ukrainian farmers from the beginning of 2016/2017 marketing year (July 2016 - June 2017) exported 28.65 million tons of grain, which is by 2.99 million tons more than in the same period last year. Ukraine exported 13.33 million tons of wheat, which is by 1.78 million tons more than in the same period the previous marketing year. Exports of barley for the reporting period amounted to 4.64 million tons, which is by 0.68 million tons more than at the same period the previous marketing year. The volume of corn exports totalled 10.53 million tons, by 0.53 million tons more than in the same period of 2015/16 marketing year. For the period from 1 to 22 February 2016 Ukraine exported 2.09 million tons of grain [7].

The Black Sea region has an increased influence in the world wheat trade. In the last grain season Ukraine ranked the fifth position among world leaders of the wheat exports [8]. In addition, Ukraine increases its participation in Asian markets. During this period, the supply of Ukrainian wheat to foreign markets compared to the previous season increased by half [9]. The main domestic wheat importers last year were Egypt (13.5\%, \$ 365 million), Indonesia (12.2\%, \$ 330 million) and Thailand (11.04\%, \$ 300 million). In other countries in the reporting period wheat was shipped to $\$ 1.7$ billion [4].

Summing up the 2016/2017 marketing year, farmers are planning to set a record on grain exports, providing 41.6 million tons of crops to the foreign markets [7].

No doubt, Ukraine managed to expand sales channels for agriculture in the global market in recent years and to persuade international partners in the reliability of performance of the contract. So, trust in Ukraine as an agrarian partner will contribute to the further development of domestic production of grain and its products.

There are a few factors which can prevent the growth of grain exports:

- Unsatisfactory logistics and increased transportation costs;

- Grain prices reduction at the beginning of a new season, which affects the price situation in the domestic market;

- Imperfect system of taxation;

- Limited financial contributions [10].

- There are several ways to solve the problem:

- Improvement of grain market infrastructure;

- Technical park modernization;

- Program planning of production development;

- Attracting of long-term investment;

- Search for new markets.

Conclusions and prospects of the further investigations. Thus, the most important component of agriculture is the grain industry, which provides a basis for the country economic guarantee. Grain production is a leader in the structure of the agricultural sector of Ukraine. The welfare, ensuring of national food security, the country export abilities depend on the level of effectiveness of its development. To hold positions in the international market for the sale of grain, it is important not only to reach the new sales channel, but also to preserve and strengthen the position in the domestic food market domestic producers must constantly invest in improving the efficiency of the industry and introduce innovative technologies for the production of competitive products.

\section{References}

1. Savytskyi , O. V. (2013). Suchasnyi stan ta problemy rozvytku svitovoho rynku zernovykh kultur. Yevropeiski perspektyvy, 1, 1-13.

2. United States Department of Agriculture // Foreign Agricultural Service / Grain: World Markets and Trade. Retrieved February, 2017, from https://apps.fas.usda.gov/psdonline/app/index.html\#/app/downloads 
3. Uriadovyi portal. Informatsiia shchodo valovoho zboru osnovnykh silskohospodarskykh kultur u 2016 r. ta stanu posivu ozymykh kultur pid urozhai 2017 r. Retrieved February, 2017, from http://www.kmu.gov.ua/control/uk/publish/article?art_id=249619933\&cat_id=244277212

4. Medium-term prospects for EU agricultural markets and income 2016-2026. Retrieved February, 2017, from https://ec.europa.eu/agriculture/markets-and-prices/medium-term-outlook_en

5. Lupenko, Iu. O. (2013). Balansy silskohospodarskoi produktsii ta prodovolstva. K.: NNTs IAE.

6. Food and Agriculture Organization of the United Nations. Reports and statistical data. Retrieved February, 2017, from http://www.fao.org/faostat/en/\#data/QC

7. Ministerstvo ahrarnoi polityky ta prodovolstva Ukrainy. Monitorynh stanu rozvytku APK. Retrieved February, 2017, from http://minagro.gov.ua/monitoring?tid_hierachy=1218

8. Samarina, I. (2015). Yak svit vplyvaie na rynok zernovykh v Ukraini (Vol. 5). Ahrobiznes sohodni.

9. Nikishyna, O. V. (n.d.). Stratehichni oriientyry rozvytku zernovoho rynku Ukrainy. Retrieved February, 2017, from http://www.confcontact.com/20110629/6_nikish.htm

10. Petrenko , I. (2016). 6 holovnykh kultur: prohnoz tsin i rentabelnosti. Retrieved from http://www.agrobusiness.com.ua/ekonomichnyi-gektar/6593-6-golovnykh-kultur-prognoz-tsin-i-rentabelnosti.html

Received 05 February 2017

Approved 19 February 2017

Available in Internet 31.03.2017

\author{
Фомичева Е.Б \\ аспирант \\ кафедра управления бизнесом \\ Одесская национальная академия пищевых технологий \\ ул. Канатная, 112, г. Одесса, Украина, 65039 \\ E-mail: ket1588@mail.ru
}

\title{
ТЕНДЕНЦИИ ЗЕРНОВОГО РЫНКА УКРАИНЫ
}

В статье исследовано современное состояние зерновой отрасли Украины, определены основные проблемы и тенденции ее развития в современных условиях хозяйствования. Исследован экспортный потенциал зернового хозяйства, обоснованна экономическая целесообразность и перспективы развития зерновой отрасли в Украине, проанализированы и обобщены объемы производства и потребления зерновых культур в мире.

На основе анализа, следует отметить, что зерновой сектор Украины является стратегической отраслью экономики государства и определяет объемы предложения и стоимость основных видов продовольствия для населения страны, в частности продуктов переработки зерна и продукции животноводства; формирует существенную долю доходов сельскохозяйственных производителей; определяет состояние и тенденции развития сельских территорий; формирует валютные доходы государства за счет экспорта. Зерновая отрасль является источником устойчивого развития большинства отраслей агропромышленного комплекса и основой аграрного экспорта страны.

Констатируя весомость полученных научных результатов в области теории и практики эффективности производства и развития рынка зерна, выделено, что на сегодня недостаточно исследованными являются вопросы комплексного изучения проблем производства и реализации зерна в условиях формирования регионального и национального зерновых рынков.

Проведенные исследования показали, что на протяжении последних лет Украина укрепила свои позиции на международном аграрном рынке и расширила каналы сбыта агропродукции на мировом рынке. Поэтому доверие к Украине, как к аграрному партнеру, будет способствовать в дальнейшем развитию внутреннего производства зерна и продуктов его переработки. Новый зерновой сезон обозначится повышением международной торговой активности.

Таким образом важнейшей составляющей агропромышленного комплекса является зерновая отрасль, которая определяет основу экономической безопасности страны.

Ключевые слова: агропромышленный комплекс, рынок зерна, урожайность, экспортный потенциал, мировой рынок зерновых культур. 


\author{
Фомічова К.Б. \\ аспірант \\ кафедра управління бізнесом \\ Одеська національна академія харчових технологій \\ вул. Канатна, 112, м. Одеса, Україна, 65039 \\ E-mail: ket1588@mail.ru
}

\title{
ТЕНДЕНЦІї ЗЕРНОВОГО РИНКУ УКРАЇНИ
}

У статті досліджено сучасний стан зернової галузі України, визначено основні проблеми й тенденції ії̈ розвитку в сучасних умовах господарювання. Досліджено експортний потенціал зернового господарства, обґрунтовано економічну доцільність та перспективи розвитку зернової галузі в Україні, проаналізовані та узагальнені обсяги виробництва та споживання зернових культур у світі.

На основі аналізу, слід зазначити, що зерновий сектор України є стратегічною галуззю економіки держави та визначає обсяги пропозиції і вартість основних видів продовольства для населення країни, зокрема продуктів переробки зерна і продукції тваринництва; фрормує істотну частку доходів сільськогосподарських виробників; визначає стан і тенденції розвитку сільських територій; формує валютні доходи держави за рахунок експорту. Зернова галузь є джерелом сталого розвитку більшості галузей агропромислового комплексу і основою аграрного експорту держави.

Констатуючи вагомість отриманих наукових результатів у сфері теорії і практики ефективності виробництва й розвитку ринку зерна, виокремлено, що на сьогодні недостатньо дослідженими $є$ питання комплексного вивчення проблем виробництва та реалізації зерна в умовах формування регіонального та національного зернових ринків.

Проведені дослідження показали, що упродовж останніх років Україна зміцнила свої позиції на міжнародному аграрному ринку та розширила канали збуту агропродукції на світовому ринку. Тож довіра до України як аграрного партнера сприятиме в подальшому розвитку внутрішнього виробництва зерна та продуктів його переробки. Новий зерновий сезон відзначатиметься підвищенням міжнародної торгівельної активності.

Отже, найважливішою складовою агропромислового комплексу є зернова галузь, що визначає основу економічної безпеки країни.

Ключові слова: агропромисловий комплекс, ринок зерна, урожайність, експортний потенціал, світовий ринок зернових культур.

\section{Література}

1.Савицький О. В. Сучасний стан та проблеми розвитку світового ринку зернових культур [Електронний ресурс] / О.В. Савицький // Європейські перспективи. - 2013. - № 1. - Режим доступу: file:///C:/Users/User/Downloads/evpe_2013_1_38.pdf

2. United States Department of Agriculture // Foreign Agricultural Service / Grain: World Markets and Trade.

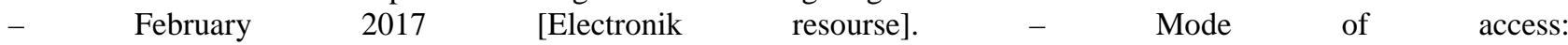
https://apps.fas.usda.gov/psdonline/app/index.html\#/app/downloads

3. Урядовий портал. Інформація щодо валового збору основних сільськогосподарських культур у 2016 p. та стану посіву озимих культур під урожай 2017 p. [Електронний ресурс]. - Режим доступу: http://www.kmu.gov.ua/control/uk/publish/article?art_id=249619933\&cat_id=244277212

4. Medium-term prospects for EU agricultural markets and income 2016-2026 [Electronik resourse]. - Mode of access: https://ec.europa.eu/agriculture/markets-and-prices/medium-term-outlook_en

5. Лупенко Ю.О. Баланси сільськогосподарської продукції та продовольства / Ю.О. Лупенко О.М. Шпичак та ін. - К.: ННЦ IAE, 2013. - C.74

6. Food and Agriculture Organization of the United Nations. Reports and statistical data. [Electronik resourse]. - Mode of access: http://www.fao.org/faostat/en/\#data/QC

7. Міністерство аграрної політики та продовольства України. Моніторинг стану розвитку АПК [Електронний ресурс]. - Режим доступу: http://minagro.gov.ua/monitoring?tid hierachy=1218

8. Самаріна I. Як світ впливає на ринок зернових в Україні [Електронний ресурс] / I. Самаріна // Агробізнес сьогодні. - 2015. - №5 (300). - Режим доступу: http://www.agro-business.com.ua/

9. Нікішина О. В. Стратегічні орієнтири розвитку зернового ринку України [Електронний ресурс] / О. В. Нікішина. - Режим доступу: http://www.confcontact.com/20110629/6 nikish.htm

10. Петренко I. 6 головних культур: прогноз цін і рентабельності [Електронний ресурс] / І.Петренко // Агробізнес сьогодні. - 2016. - №18. - Режим доступу: http://www.agro-business.com.ua/ekonomichnyigektar/6593-6-golovnykh-kultur-prognoz-tsin-i-rentabelnosti.html 